UDC 636.085.622

DOI: 10.37128/2520-6168-2021-3-6

Vol. 114, No 3/2021

\title{
RESEARCH OF THE RHEOLOGICAL PARAMETERS OF FEED GRAIN IN THE PROCESS OF THE COMBINED IMPACT-CUTTING GRINDING
}

\author{
Ihor Kupchuk, Ph.D. in Engineering, Associate Professor \\ Yuliia Poberezhets, Ph.D. in Agriculture, Associate Professor \\ Ruslan Kravets, Dr. Sc. in Pedagogy, Associate Professor \\ Vinnytsia National Agrarian University
}

\author{
Купчук Ігор Миколайович, к.т.Н., доцент \\ Побережець Юлія Миколаївна, к.с.-г.н., доцент \\ Кравець Руслан Андрійович, д.П.н., доцент \\ Вінницький національний аграрний університет
}

Taking into consideration current realities and various factors, which create difficulties for the effective functioning of Ukraine's national economic system, the Agro-Industrial Complex of Ukraine acts as the most stable part of it, that is characterized by conservatism and is one of the main and stable cross-sectoral formations due to revenues. However, despite the strategic priority of the AIC, the high level of energy consumption by domestic producers does not enable providing an appropriate level of competitiveness of Ukraine's AIC in domestic and foreign markets, at the same time the rationalisation of energy use necessitates the substantiation of the energy-saving variant of its development by implementing energy-efficient machines and technologies in the system of feed preparation and feeding animals.

In the technological process of feed preparation, the share of energy consumption for grinding can be more than 50\%. Thus, it becomes obvious that the profitability and competitiveness of the livestock industry largely depend on the energy efficiency of realizing this technological operation, and the reduction of energy intensity in this process is an urgent task. Modelling energy-saturated mechanical processes, particularly for the grinding operation, it is necessary to consider structural-mechanical properties of the product, its ability to deform in different modes of interaction with the executive body of the technological machine.

The six-link mechanical-rheological model, which is built by combining the simplest models of rheological bodies and enables reproducing the structural and mechanical properties of the object of processing - maize grain with the required degree of reliability, has been offered in the article.

Theoretical research of the rheological characteristics of the material, including the assessment of the relative deformation of the maize grain in the grinding process using he impact-cutting method depending on the moisture content and internal force factors, has been conducted. In the future, the obtained results will be used to evaluate the parameters of plastic and elastic absolute deformations in the material while studying the kinetics of the grinding process.

Key words: local stresses, deformation, elasticity, viscosity, rheological model, structural-mechanical properties.

F. 48. Fig. 5. Table. 1. Ref. 18.

\section{Introduction}

Scientists point outs that [1], feed preparation constitutes 45-50 percent of the cost of prepared livestock products. In this case, the estimated energy costs for technological operations are distributed in the following way: transportation $-10 \ldots 20 \%$, dosing $-5 \ldots 8 \%$, grinding (including grain material) - up to $45 \ldots 65 \%$ of total costs, that is approximately $33 \%$ of the cost of finished products $[1,2]$.

In opinions of many scientists, a significant condition for the organization of complete feeding for animals and poultry is the efficient use of grain feed and their rational preparation for feeding. The share of concentrated feeds in the total feed balance is $29 . .32 \%$. Among cereals, maize grain has the highest nutritional value. It contains lots of carbohydrates, mainly starch (approximately 70\%), fat (up to 6\% or more), the amount of protein (9-12\%). Nutritional value of $1 \mathrm{~kg}$ of grain $-1,33$ fodder units. and $67-73 \mathrm{~g}$ of digestible protein. The efficiency of using grain without prior preparation is reduced by $10 . . .20 \%[3,4,5,6]$.

The most common ways of using grain in feeding animals is to introduce it into various feed mixtures and compound feeds, crushed or in the form of flattened, extruded, micronized and so on. One of the main ways of preparing feeds for feeding animals is grinding. Grinding is the main way of preparing grains for 


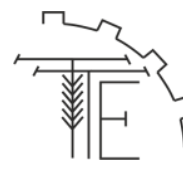

feeding animals, which allows increasing the digestibility of nutrients by $15-30 \%[4,6]$.

Ibatullin I.I. and Zhukorskyi O.M. [6] believe that the degree of grinding influences the amount and enzymatic activity of digestive juices, the rate of passage of food through different parts of the digestive tract and, thus, the digestibility of nutrients and the productivity of animals. Consequently, the researches are aimed at intensifying the process of grinding the material for further use in the feed preparation system under the condition of reducing energy consumption and providing the required quality of the original product, are relevant and have practical value.

The creation of modern high-performance technological systems, including, for example, the system «crusher - grain material» is based on the mandatory justification of certain applied engineering and design solutions. One of the stages of such design is to determine the patterns of the movement of the machine and define the optimal parameters of the technological process on this basis. An essential aspect is the substantiation and choice of the calculation model, which adequately reflects the real movement of the system «machine - raw materials».

The initial data for modelling the processes of mechanical grinding are information on the structuralmechanical properties of the processable object [7, 8], the kinetics of deformation [9], the critical values of the internal force factors at which the destruction of the structure occurs $[10,11]$. The process and the nature of the destruction of the grain result from the modes of its contact interaction with the executive body of the crusher, including the configuration and geometric parameters of the impactors. So, to obtain a comprehensive mathematical model that would cover the specifics of the contact interaction of the processable object with the executive bodies of the machine is a necessary condition for the development and analysis of the mechanicalrheological model of maize grain, which determines the research aim.

\section{Research aim and objectives}

The aim of the article is to assess the process of relative deformation of maize grain during combined grinding by impact-cutting, developing and analysing the mechanical-rheological model of the material.

\section{Materials and methods}

The scientific provisions of the research are based on the mechanics of contact interaction, dispersed mechanics, solid mechanics.

Having derived the equations of elastic and plastic deformation of grain, rheological methods of researching dispersed systems, empirical constants and reference data on the structure, physical properties, chemical composition, absolute mass, biological features of anatomical parts of a maize grain: germ, endosperm, outer and inner pericarps have been used (Fig. 1a). The solution of analytical expressions and graphical interpretation of the obtained results have been performed using specialised software MS Excel 2020, MathCad 15.
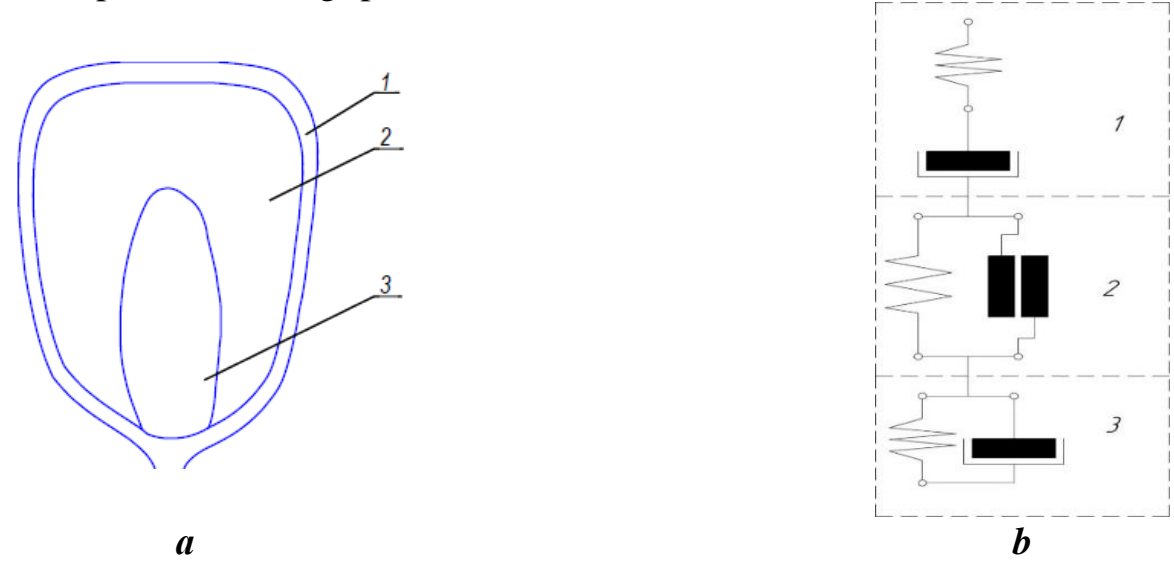

Fig. 1. Maize grain: a) anatomical structure; b) rheological model; 1 -hull; 2 -endosperm; 3 -germ.

The object of the research is the structural-mechanical properties of a maize grain. The subject of the research is the regularities of the process of deforming a grain under the action of external load of the cutting edge of the crusher's impactor.

\section{Results and discussion}

Maize grain is the only entire organic compound that is sharply heterogeneous in its structure, physical properties, chemical composition, absolute mass, biological purpose of the anatomical parts. 
Thus, this processable object can be characterised as an elastic-viscous-plastic, colloidal, capillaryporous body, with a protein framework, starch filler and cellulose hull, that makes it difficult to carry out experimental assessment of mechanical-technological properties of the processable object. In order to formalize the objective of researching the process of deforming a grain, we have proposed a simplified sixlink model of a maize grain as the most acceptable rheological model for a wide range of actions (Fig. 1b).

The proposed model is a sequential connection of the model of the Maxwell ideal body (describes the elastic hull of the grain containing bound moisture), the body is a parallel connection of Hooke's model of the ideal-elastic body with Saint-Venant's model of the ideal plastic body (describes the behaviour of floury endosperm containing an elastic-plastic starch filler) and the model of the Kelvin body (describes the behaviour of an elastic germ containing molecular moisture).

For a mathematical description of the behaviour of the proposed rheological model of the grain (Fig. 1b) under the influence of the applied force $\mathrm{F}$ let us consider separately each of the three bodies listed above: M, HStV and K. The Maxwell body (M) (Fig. 2) is a sequential connection of Hooke's ideal-elastic body $(\mathrm{H})$ with Newtonian ideal-viscous fluid $(\mathrm{N})$.

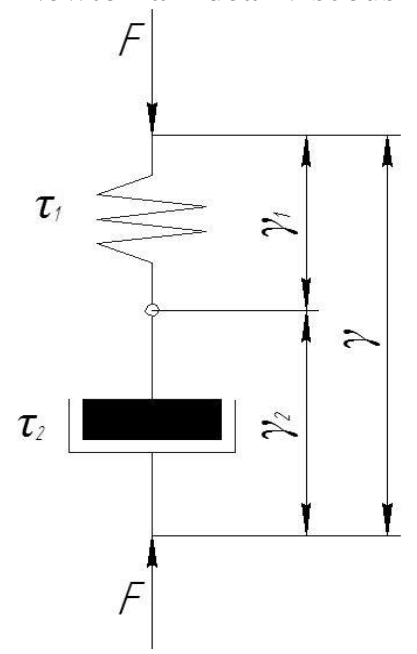

Fig. 2. Rheological model of the a maize grain hull

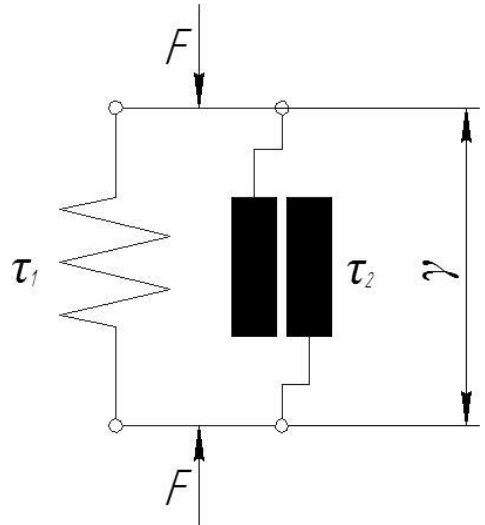

Fig. 3. Rheological model of maize grain endosperm

As a wide-ranging uniform pressure in each material, regardless of its rheological properties, causes elastic deformation, accompanied by tangential stresses, in each of these three bodies (M, HStV and $\mathrm{K}$ ), under the influence of the applied force, the same tangential stresses $\tau$ will occur. $[12,13]$.

On the basis of the above mentioned, under the action of the applied force F, there is a tangential stress $\tau$, which for each element M-body is the same:

$$
\tau_{1}=\tau_{2}=\tau,
$$

and the deformation $\gamma$, that occurs in M-body, is equal to the sum of the deformations of each of its elements:

$$
\gamma=\gamma_{1}+\gamma_{2} \text {. }
$$

The tangential stress $\tau$, that takes place in the H-body, can be determined according to Hooke's law by the formula:

$$
\tau=\mu \cdot \gamma_{1} \text {, }
$$

where the deformation, that occurs in the H-body, can be found:

$$
\gamma_{1}=\frac{\tau}{\mu},
$$

where: $\mu$ is the shear modulus.

Differentiating equation (4), we shall obtain the equation of the strain rate that occurs in H-body:

$$
\frac{d \gamma_{1}}{d t}=\frac{1}{\mu} \cdot \frac{d \tau}{d t} .
$$

The tangential stress $\tau$, which occurs in $\mathrm{N}$ - body, can be determined by the formula:

$$
\tau=\eta \cdot \frac{\mathrm{d} \gamma_{2}}{\mathrm{dt}},
$$


so we obtain the equation of the rate of deformation, that is taking place in the body:

$$
\frac{\mathrm{d} \gamma_{2}}{\mathrm{dt}}=\frac{\tau}{\eta}
$$

where $\eta$ is the coefficient of viscosity.

Differentiating equation (2), we shall obtain the equation of the strain rate that occurs in M-body:

$$
\frac{d \gamma}{d t}=\frac{d \gamma_{1}}{d t}+\frac{d \gamma_{2}}{d t}
$$

Substituting equations (5) and (7) into equation (8), we shall finally obtain the equation of the strain rate that occurs in M-body:

$$
\frac{d \gamma}{d t}=\frac{1}{\mu} \cdot \frac{d \tau}{d t}+\frac{\tau}{\eta} .
$$

HStV body (Fig. 3) is a parallel connection of the perfectly elastic Hooke's body (H) with SaintVenant's ideal-plastic body ( $\mathrm{StV})$.

When the elements are connected in parallel, the total voltage on the model is equal to the sum of the voltages on each element, the tangential voltage $\tau$ that occurs in HStV body, can be defined in the following way:

$$
\tau=\tau_{1}+\tau_{2} .
$$

The tangential stress $\tau 1$, that occurs in H-body:

$$
\tau_{1}=\mu \cdot \gamma_{1} \text {, }
$$

where: $\mu$ is the shear modulus, $\gamma_{1}$ is the deformation, that occurs in $\mathrm{H}$ body.

The tangential stress $\tau_{2}$, which take place in HStV body is:

$$
\tau_{2}=\tau_{\mathrm{T}},
$$

$\tau_{\mathrm{T}}$ is the shear yield strength.

Substituting equations (11) and (12) into equation (10) we obtain:

$$
\tau=\mu \cdot \gamma_{1}+\tau_{\mathrm{T}}
$$

In the case of parallel connection of elements the total deformation of model $\gamma$ is equal to the deformation of each element:

$$
\gamma_{1}=\gamma_{2}=\gamma
$$

then the equation of deformation, that occurs in $\mathrm{HStV}$ body, can be expressed by the equation (13):

$$
\gamma=\frac{\tau-\tau_{T}}{\mu} .
$$

Differentiating equation (15), we obtain the equation of the strain rate, that occurs in HStV body:

$$
\frac{d \gamma}{d t}=\frac{1}{\mu} \cdot\left(\frac{d \tau}{d t}-\frac{d \tau_{T}}{d t}\right) .
$$

As the shear yield strength is constant value $\tau_{\mathrm{T}}=$ const, then equation (16) will take the following form:

$$
\frac{d \gamma}{d t}=\frac{1}{\mu} \cdot \frac{d \tau}{d t}
$$

The Kelvin-Voigt body (K) (Fig. 4) is a parallel connection of Hooke's ideal-elastic body (H) with Newtonian ideal-viscous fluid $(\mathrm{N})$.

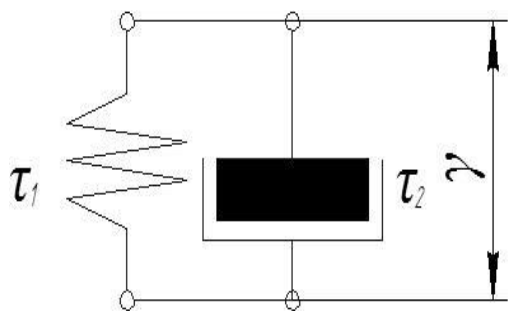

Fig. 4. Rheological model of maize grain germ

The tangential stress $\tau$, that appears in K-body, can be found using the formula:

$$
\tau=\tau_{1}+\tau_{2} \text {. }
$$




\section{Vol. 114, No 3/ 2021}

According to Hooke's law, the tangential stress $\tau_{1}$ arises in H-body:

$$
\tau_{1}=\mu \cdot \gamma_{1} \text {, }
$$

where: $\mu$ is the shear modulus, $\gamma 1$ is the deformation, which takes place in $\mathrm{H}$-body.

The tangential stress $\tau_{2}$, that occurs in $\mathrm{N}$ - body:

$$
\tau_{2}=\eta \cdot \frac{d \gamma_{2}}{d t},
$$

where: $\eta$ is the shear viscosity coefficient.

Substituting equations (19) and (20) into equation (18), we shall obtain:

$$
\tau=\mu \cdot \gamma_{1}+\eta \cdot \frac{d \gamma_{2}}{d t} .
$$

Differentiating equation (21), we shall obtain:

$$
\frac{d \tau}{d t}=\mu \cdot \frac{d \gamma_{1}}{d t}+\eta \cdot \frac{d^{2} \gamma_{2}}{d t^{2}},
$$

then:

$$
\frac{\eta}{\mu} \cdot \frac{d^{2} \gamma_{2}}{d t^{2}}+\frac{d \gamma_{1}}{d t}=\frac{1}{\mu} \cdot \frac{d \tau}{d t}
$$

Absolute deformation of model $\gamma$ :

$$
\gamma_{1}=\gamma_{2}=\gamma
$$

After that the equation (23) will take the following form:

$$
\frac{\eta}{\mu} \cdot \frac{d^{2} \gamma}{d t^{2}}+\frac{d \gamma}{d t}=\frac{1}{\mu} \cdot \frac{d \tau}{d t} .
$$

So the equation of the strain rate, that occurs in K-body, can be obtained:

$$
\frac{d \gamma}{d t}=\frac{1}{\mu} \cdot \frac{d \tau}{d t}-\frac{\eta}{\mu} \cdot \frac{d^{2} \gamma}{d t^{2}},
$$

or:

$$
\frac{d \gamma}{d t}=\frac{1}{\mu} \cdot\left(\frac{d \tau}{d t}-\eta \cdot \frac{d^{2} \gamma}{d t^{2}}\right) .
$$

Subsequently, let us consider a series connection of M and HStV bodies, in which the deformations, which occur in them, are added:

$$
\gamma=\gamma_{1}+\gamma_{2} .
$$

Differentiating equation (28), we shall obtain the equation of the strain rate that occurs in the M-HStV-body:

$$
\frac{d \gamma}{d t}=\frac{d \gamma_{1}}{d t}+\frac{d \gamma_{2}}{d t} .
$$

Substituting the equation of the strain rate, that occurs in the M-body (9), and the equation of the strain rate, that occurs in the HStV body (17) in equation (29), we shall finally obtain the equation of the strain rate, that occurs in the M-HStV-body:

$$
\frac{d \gamma}{d t}=\frac{1}{\mu_{1}} \cdot \frac{d \tau}{d t}+\frac{\tau}{\eta}+\frac{1}{\mu_{2}} \cdot \frac{d \tau}{d t},
$$

or:

$$
\frac{d \gamma}{d t}=\frac{1}{\mu_{1}} \cdot \frac{d \tau}{d t}+\frac{1}{\mu_{2}} \cdot \frac{d \tau}{d t}+\frac{\tau}{\eta} .
$$

The series connection of M-HStV and $\mathrm{K}$ bodies enables building the proposed rheological model of grain (Fig. 2). Taking into consideration the above mentioned data, we shall find the deformation that occurs in this series connection:

$$
\gamma=\gamma_{1}+\gamma_{2}
$$

Differentiating equation (32), we shall obtain the equation of the strain rate that occurs in the M-HStV-K-body:

$$
\frac{d \gamma}{d t}=\frac{d \gamma_{1}}{d t}+\frac{d \gamma_{2}}{d t} .
$$


Substituting the equation of the strain rate, that occurs in the M-HStV-body (31), and equation (27) in equation (33), we shall finally obtain the equation of the strain rate that occurs in the M-HStV-K-body:

$$
\frac{d \gamma}{d t}=\frac{1}{\mu_{1}} \cdot \frac{d \tau}{d t}+\frac{1}{\mu_{2}} \cdot \frac{d \tau}{d t}+\frac{\tau}{\eta_{1}}+\frac{1}{\mu_{3}} \cdot\left(\frac{d \tau}{d t}-\eta_{2} \cdot \frac{d^{2} \gamma}{d t^{2}}\right)
$$

then:

$$
\frac{d \gamma}{d t}=\frac{1}{\mu_{1}} \cdot \frac{d \tau}{d t}+\frac{1}{\mu_{2}} \cdot \frac{d \tau}{d t}+\frac{\tau}{\eta_{1}}+\frac{1}{\mu_{3}} \cdot \frac{d \tau}{d t}-\frac{\eta_{2}}{\mu_{3}} \cdot \frac{d^{2} \gamma}{d t^{2}}
$$

or:

$$
\frac{\eta_{2}}{\mu_{3}} \cdot \frac{d^{2} \gamma}{d t^{2}}+\frac{d \gamma}{d t}=\frac{1}{\mu_{1}} \cdot \frac{d \tau}{d t}+\frac{1}{\mu_{2}} \cdot \frac{d \tau}{d t}+\frac{1}{\mu_{3}} \cdot \frac{d \tau}{d t}+\frac{\tau}{\eta_{1}}
$$

As the proposed rheological model (Fig. 1b) structurally consists of three complex bodies (M, HStV and $\mathrm{K}$ ), but mathematically describes one body - grain, then the coefficients of elasticity and viscosity of these bodies can be considered as equal:

$$
\begin{gathered}
\mu_{1}=\mu_{2}=\mu_{3}=\mu, \\
\eta_{1}=\eta_{2}=\eta .
\end{gathered}
$$

So equation (36) will take the following form:

Consequently:

$$
\frac{\eta}{\mu} \cdot \frac{d^{2} \gamma}{d t^{2}}+\frac{d \gamma}{d t}=\frac{1}{\mu} \cdot \frac{d \tau}{d t}+\frac{1}{\mu} \cdot \frac{d \tau}{d t}+\frac{1}{\mu} \cdot \frac{d \tau}{d t}+\frac{\tau}{\eta}
$$

$$
\frac{\eta}{\mu} \cdot \frac{d^{2} \gamma}{d t^{2}}+\frac{d \gamma}{d t}=\frac{3}{\mu} \cdot \frac{d \tau}{d t}+\frac{\tau}{\eta}
$$

Dividing the left and right parts of equation (40) by $\frac{\eta}{\mu}$, we shall obtain:

$$
\frac{d^{2} \gamma}{d t^{2}}+\frac{\mu}{\eta} \cdot \frac{d \gamma}{d t}=\frac{3}{\eta} \cdot \frac{d \tau}{d t}+\frac{\mu \cdot \tau}{\eta^{2}}
$$

The obtained expression is a second order differential equation. To solve it, we use the method of Reduction of order derivatives by means of a transition. To do this, we shall denote:

$$
\begin{aligned}
& \frac{d \gamma}{d t}=z(t), \\
& \frac{d^{2} \gamma}{d t^{2}}=\frac{d z}{d t} .
\end{aligned}
$$

Then equation (41) can be written as a first-order differential equation:

$$
\frac{d z}{d t}+\frac{\mu}{\eta} \cdot z=\frac{3}{\eta} \cdot \frac{d \tau}{d t}+\frac{\mu \cdot \tau}{\eta^{2}}
$$

The solution of this differential equation will be the expression of the following form:

$$
z=e^{-\int_{0}^{\prime} \frac{\mu}{\eta} d t}\left[\int_{0}^{t}\left(\frac{3}{\eta} \cdot \frac{d \tau}{d t}+\frac{\mu \cdot \tau}{\eta^{2}}\right) \cdot e^{\int_{0}^{\prime} \frac{\mu}{\eta} d t} d t+C_{0}\right] .
$$

Thus, like at the beginning of the process of grain destruction by impact cutting it is in a relaxed state, arbitrary constant $\mathrm{C}_{0}=0$ :

$$
z=e^{-\int_{0}^{t} \frac{\mu}{\eta} d t}\left[\int_{0}^{t}\left(\frac{3}{\eta} \cdot \frac{d \tau}{d t}+\frac{\mu \cdot \tau}{\eta^{2}}\right) \cdot e^{\int_{0}^{t} \frac{\mu}{\eta} d t} d t\right] .
$$

The process of grain destruction of by impact cutting consists of three successive phases. The first phase is the contact of the grain with the blade, resulting in a compression stress, which is characterised by the magnitude of its deformation. The second phase occurs when the compressive stress reaches a certain limit caused by the strength of the grain, and is manifested in the formation of cracks in it. The third phase is the 


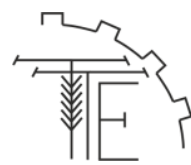

ultimate destruction of the coherent structure [14].

Since maize grain is an aggregate of individual bodies of inhomogeneous structure, some of which have a lower yield strength than others. If some force $\mathrm{F}$ is applied to the body, some parts of it are subjected only to elastic deformations, and others begin to flow, after a while they are gradually released from stress and it begins to distribute to more elastic parts of the grain, therefore, the stress in this part increases and deformation increases $[15,16]$.

After the inverse transition according to equations $(42,43)$ we shall obtain:

$$
\frac{d \gamma}{d t}=e^{-\int_{0}^{t} \frac{\mu}{\eta} d t}\left[\int_{0}^{t}\left(\frac{3}{\eta} \cdot \frac{d \tau}{d t}+\frac{\mu \cdot \tau}{\eta^{2}}\right) \cdot e^{\int_{0}^{t} \frac{\mu}{\eta} d t} d t\right]
$$

Integrating equation (47), we shall finally obtain the equation for defining the value of deformation that occurs in M-HStV-K body:

$$
\gamma=\left[\tau\left(\frac{e^{-\frac{2 \mu \cdot t}{\eta}}-1}{2 \mu}-\frac{e^{-\frac{\mu \cdot t}{\eta}}-1}{\mu}\right)\right]^{\frac{\mu \cdot t}{\eta}}
$$

Since the structural and mechanical properties of the material are significantly affected by moisture content, in table 1. the values of rheological coefficients for maize grain are presented at a moisture content of $13 \%$ to $26 \%[17,18]$.

Values of rheological coefficients for maize grain [18]

\begin{tabular}{|l|c|c|c|c|c|}
\hline Moisture content $\mathrm{W}, \%$ & $13-14$ & $16-17$ & $19-20$ & $22-23$ & $25-26$ \\
\hline Shear modulus, $\mu(\mathrm{MPa})$ & 8,61 & 5,07 & 3,05 & 2,43 & 2,25 \\
\hline Viscosity coefficient, $\eta(\mathrm{MPa} \cdot \mathrm{s})$ & 29,68 & 20,22 & 14,22 & 11,51 & 10,87 \\
\hline Strength limit, $\boldsymbol{\tau}_{\max }(\mathrm{MPa})$ & 2,9 & 1,75 & 1,035 & 0,875 & 0,825 \\
\hline
\end{tabular}

This values which have been obtained by other scientists and used by us as empirical constants for solving equation (48) and graphical interpretation of the laws of deformation of feed grain (Fig. 5).

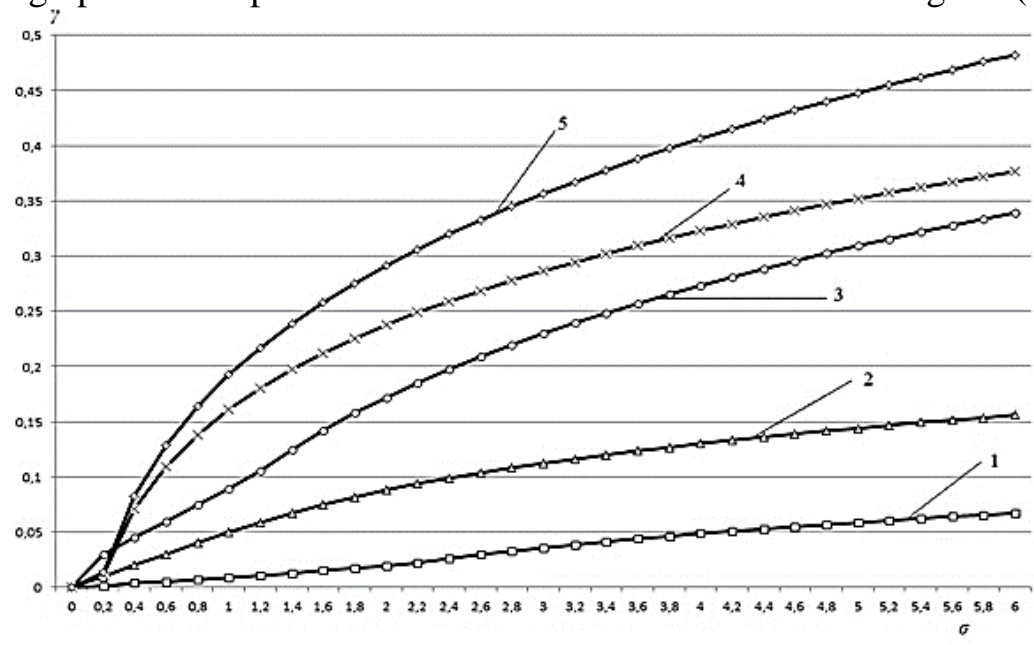

Fig. 5. Dependence of the relative deformation of maize grain on normal stresses at moisture values: 1 . $W=13-14 \% ; 2 . W=16-17 \% ; 3 . W=19-20 \% ; 4 . W=22-23 \% ; 5 . W=25-26 \%$.

\section{Conclusions and further research prospects}

Having analysed the graphical dependences (Fig. 5) we have concluded that the increase in the applied force, as a consequence of normal stresses in the grain, leads to a nonlinear increase in its relative deformation. At the initial stage of applying force to the grain, the material has mostly elastic deformations, as evidenced by the characteristic shape of the curve. Thus, for grain relative humidity $\mathrm{W}=25-26 \%$ within normal stresses $0 \ldots 0,38 \mathrm{MPa}$, there is a rapid increase in relative deformation to 0,08 , the graphical representation of which, with certain assumptions, can be described by the equation of the line (Hooke's law). 
With an increase of $\sigma 0,38 \ldots 1,65 \mathrm{MPa}$, the shape of the deformation curve changes slightly, and takes the form of a parabola branch, which indicates the predominant plastic deformations occurring in the grain, until its destruction at 1,65 $\mathrm{MPa}$ and deformation of 0,28 . These conclusions will enable assessing the values of plastic and elastic absolute deformations in the material while researching the kinetics of the grinding process.

\section{References}

[1] Kaletnik, H. M., Kulyk, M. F. \& Hlushko, Ya. T. (2006). Enerhooshchadni tekhnolohii kormiv-osnova konkurentozdatnosti tvarynnytstva [Energy-saving feed technologies - the basis of animal competitiveness]. Vinnytsia : Teza. [in Ukrainian].

[2] Yanovych, V.P.\& Kaletnik, H. M. (2017). Obgruntuvannia rezhymnykh ta konstruktyvnykh parametriv hiratsiinoho mlyna dlia vyrobnytstva vysokoaktyvnykh premiksiv [Substantiation of regime and design parameters of gyration mill for production of highly active premixes]. Vibratsii $v$ tekhnitsi ta tekhnolohiiakh, 1 (84), 15-21 [in Ukrainian].

[3] Gnoievoi, V.I. (2017). Biomorfologicheskaia organizatsiia i pitatelnost kormov [Biomorphological organization and nutritional value of feeds]. Kharkiv. [in Russian].

[4] Chudak, R.A., Ushakov, V.M., Poberezhets, Y.M., Lotka, H.I., Polishchuk, T.V. \& Kazmiruk, L.V. (2020). Effect of Echinacea pallida supplementation on the amino acid and fatty acid composition of Pharaoh Quail meat. Ukrainian Journal of Ecology, Vol. 10 (2):302-307. DOI: 10.15421/2020_101. [in English].

[5] Yehorov, B.V. (2018). Kontrol yakosti ta bezpeka produktsii v haluzi (kombikormova haluz) [Quality control and product safety in the industry (feed industry)]. Oldi. [in Ukrainian].

[6] Ibatullin, I.I., \& Zhukorskyi, O.M. (2016). Dovidnyk z povnotsinnoi hodivli silskohospodarskykh tvaryn [Reference book of complete feeding of farm animals]. K. Agrar. Science. [in Ukrainian].

[7] Kupchuk, I. M. (2019). Eksperymentalni doslidzhennia protsesu podribnennia furazhnoho zerna vibratsiinoiu dyskovoiu drobarkoiu [Experimental research of the process of grinding fodder grain with a vibrating disk crusher]. Vibrations in engineering and technology, 3 (94), 68-75 [in Ukrainian].

[8] Palamarchuk, I.P., Yanovych, V.P., \& Kupchuk, I.M. (2016). Doslidzhennia reolohichnykh kharakterystyk zernovoyi krokhmalevmisnoi syrovyny spirtovoho vyrobnytstva [Research of rheological characteristics of the cereal starch raw etanol production]. Tekhnika, enerhetyka, transport $A P K$. № 3 (95), 130-134 [in Ukrainian].

[9] Solona, O., Derevenko, I., Kupchuk, I. (2019). Determination of Plasticity for pre-deformed billet, Solid State Phenomena, 291, 110-120. https://doi.org/10.4028/www.scientific.net/ ssp.291.110 [in English].

[10] Kupchuk, I.M. (2018). Doslidzhennia protsesu podribnennia zerna dyskovym udarnym elementom [Research of the grinding grain process with a disk impact element]. Technical service of agriculture, forestry and transport systems. 11, 41-48 [in Ukrainian].

[11] Yanovych, V., Honcharuk, T., Honcharuk, I., \& Kovalova K. (2017). Design of the system to control a vibratory machine for mixing loose materials, Eastern-European Journal of Enterprise Technologies, 6, 4-13. https://doi.org/10.15587/1729-4061.2017.117635 [in English].

[12] Mazur, V.A., Honcharuk, I.V., Didur, I.M., Pantsyreva H.V., Telekalo, N.V., \& Kupchuk, I.M. (2021). Innovatsiini aspekty tekhnolohii vyroshchuvannia, zberihannia i pererobky zernobobovykh kultur [Innovative aspects of growing, storage and processing technologies for legumes]. Vinnytsia : VNAU. [in Ukrainian].

[13] Solona, O., Kovbasa, V., Kupchuk, I. (2020). Analytical study of soil strain rate with a ploughshare for uncovering slit. Agraarteadus, 31, 2, 212-218. https://doi.org/10.15159/jas.20.22 [in English].

[14] Nanka, O.V., \& Boiko, I.H. (2012). Tekhnolohiia vyrobnytstva i pererobky produktsii tvarynnytstva [Ways of reducing the energy consumption of grain feed grinding and improving the grinding quality]. Technology of production and processing livestock products. Collection of scientific works of BNAU. Bila Tserkva: BNAU, 7, 55-58 [in Ukrainian].

[15] Honcharuk, I., Kupchuk, I., Solona, O., Tokarchuk, O., \& Telekalo, N. (2021). Experimental research of oscillation parameters of vibrating-rotor crusher. Przeglad Elektrotechniczny. 97(3). 97-100. https://doi.org/10.15199/48.2021.03.19 [in English].

[16] Aliev, E. B., Bandura, V. M., Pryshliak, V. M., Yaropud, V. M., \& Trukhanska, O. O. (2018). Modeling of mechanical and technological processes of the agricultural industry INMATEH-Agricultural Engineering. 54(1), 95-104 [in English].

[17] Palamarchuk, I.P., Yanovych, V.P., \& Kupchuk, I.M. (2016). Doslidzhennia fizyko-mekhanichnykh vlastyvostei zernovoi krokhmalovmisnoi syrovyny yak obiekta tekhnolohichnoi dii spyrtovoho 
vyrobnytstva [Research of physical-mechanical properties of grain starch-containing raw materials as an object of technological action of alcohol production]. Tekhnika, enerhetyka, transport APK. №3 (95), 126-129 [in Ukrainian].

[18] Zveriev, S.V., \& Zverieva, N.S. (2007). Fizicheskiie svoistva zerna i produktov yego pererabotki [Physical properties of grain and products of its processing]. M.: DeLi print. [in Russian].

\section{ДОСЛІДЖЕННЯ РЕОЛОГІЧНИХ ПАРАМЕТРІВ ФУРАЖНОГО ЗЕРНА В ПРОЦЕСІ КОМБІНОВАНОГО УДАРНО-РІЗАЛЬНОГО ПОДРІБНЕННЯ}

В сучасних реаліях та враховуючи чинники різного роду, щзо створюють проблеми для ефективного функціонування національної економічної системи Украӥни, Агропромисловий комплекс України виступає в ролі найбільш стійкої ї̈ частини, яка характеризується консервативністю та є одним із основних та стабільних за обсягами надходжень до бюджету міжгалузевих формувань. Проте попри стратегічну пріоритетність АПК, високий рівень витрат енергоресурсів вітчизняними товаровиробниками не дозволяє забезпечити належний рівень конкурентоспроможності АПК України на внутрішньому та зовнішньому ринках, а раціоналізація енерговикористання обумовлює необхідність обгрунтування енергоощадного варіанту його розвитку шляхом застосування енергоефективних машин і технологій, у тому числі в системі приготування кормів та годівлі тварин.

В технологічному прочесі приготування кормів частка енерговитрат на подрібнення може складати більш, як 50 \%. Тому стає очевидним, щзо прибутковість та конкурентоспроможність галузі тваринництва в значній мірі залежать від енергетичної ефективності реалізації даної технологічної операції, а зниження енергоємності процесу є актуальною задачею. У моделюванні енергонасичених механічних процесів, зокрема для операції подрібнення, необхідно враховувати структурно-механічні властивості продукту, здатність його до деформування за різних режимів взаємодії з виконавчим органом технологічної машини.

В статі запропоновано шестиланкову механіко-реологічну модель, яка побудована шляхом комбінування найпростіших моделей реологічних тіл та надає змогу з необхідним ступенем достовірності відтворити структурно-механічні властивості обєкта обробки - зерна кукурудзи зубовидної.

Також здійснено теоретичне дослідження реологічних характеристик матеріалу, зокрема здійснена оцінка відносної деформації зерна кукурудзи зубовидної в процесі його подрібнення ударнорізальним способом в залежності від вологовмісту та внутрішньо-силових факторів. В подальшому отримані результати будуть використані для оцінки параметрів пластичних та пружних абсолютних деформацій в матеріалі при дослідженні кінетики процесу подрібнення.

Ключові слова: локальні напруження, деформація, пружність, в'язкість, реологічна модель, структурно-механічні властивості.

Ф. 48. Рис. 5. Табл. 1. Лім. 18.

\section{ИССЛЕДОВАНИЯ РЕОЛОГИЧЕСКИХ ПАРАМЕТРОВ ФУРАЖНОГО ЗЕРНА В ПРОЦЕССЕ КОМБИНИРОВАННОГО УДАРНО-РЕЖУЩЕГО ИЗМЕЛЬЧЕНИЯ}

В современных реалиях и учитывая факторы различного рода, которые создают проблемы для эффективного функиионирования начиональной экономической системь Украины, Агропромышленный комплекс Украины выступает в роли наиболее устойчивой ее части, которая характеризуется консервативностью и является одним из основных и стабильных по объемам поступлений в бюджет межотраслевых формирований. Однако несмотря на стратегическую приоритетность АПК, высокий уровень расходов энергоресурсов отечественными товаропроизводителями не позволяет обеспечить надлежащий уровень конкурентоспособности АПК Украины на внутреннем и внешнем рынках, а рационализация энергопотребления обусловливает необходимость обоснования энергосберегающего варианта его развития путем применения энергоэффективных машин и технологий, в том числе в системе приготовления кормов и кормления животных.

В технологическом прочессе приготовления кормов доля энергозатрат на измельчение может составлять более $50 \%$. Поэтому становится очевидным, что доходность и конкурентоспособность отрасли животноводства в значительной степени зависят от энергетической эффективности реализации данной технологической операчии, а снижение энергоемкости процесса является актуальной задачей. В моделировании энергонасыщенных механических прочессов, в частности для операчии измельчения, необходимо учитывать структурно-механические свойства продукта, 


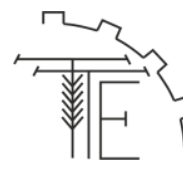

способность его к деформации при различных режимах взаимодействия с исполнительным органом технологической машины.

В статье предложено шестизвенную механико-реологическую модель, которая построена путем комбинирования простейших моделей реологических тел и дает возможность с необходимой степенью достоверности воссоздать структурно-механические свойства объекта обработки - зерна кукурузы зубовидной.

Также осуществлено теоретическое исследование реологических характеристик материала, в частности осуществлена оценка относительной деформации зерна кукурузы зубовидной в процессе его измельчения ударно-режущчим способом в зависимости от влагосодержания и внутренне силовых факторов. В дальнейшем полученнье результать будут использовань для оченки параметров пластических и упругих абсолютных деформаџий в материале при исследовании кинетики процесса измельчения.

Ключевые слова: локальные напряжения, деформаџия, упругость, вязкость, реологическая модель, структурно-механические свойства.

Ф. 48. Рис. 5. Табл. 1. Лит. 18.

\section{INFORMATION ABOUT THE AUTHORS}

Ihor Kupchuk - PhD in Engineering, Associate Professor of the Department of General Technical Disciplines and Labour Protection of Vinnytsia National Agrarian University (3 Soniachna Str., Vinnytsia, Ukraine, 21000, e-mail: kupchuk.igor@i.ua, http://orcid.org/0000-0002-2973-6914 ).

Yuliia Poberezhets - PhD in Agriculture, Associate Professor of the Department of Veterinary Medicine, Hygiene and Animal Breeding of Vinnytsia National Agrarian University (3 Soniachna Str., Vinnytsia, Ukraine, 21000, +380982248856, e-mail: julia.p08@ukr.net, http://orcid.org/0000-0002-1727-6105 ).

Ruslan Kravets - Dr. Sc. in Pedagogy, Associate Professor, Head of the Department of Ukrainian and Foreign Languages of Vinnytsia National Agrarian University (3 Soniachna Str., Vinnytsia, Ukraine, 21000, e-mail: krawezj@ukr.net, https://orcid.org/0000-0002-7459-8645 ).

Купчук Ігор Миколайович - кандидат технічних наук, доцент кафедри загальнотехнічних дисциплін та охорони праці Вінницького національного аграрного університету (вул. Сонячна, 3, м. Вінниця, 21008, Україна, e-mail: kupchuk.igor@i.ua, http://orcid.org/0000-0002-2973-6914 ).

Побережець Юлія Миколаївна - кандидат с.-г. наук, доцент кафедри ветеринарії, гігієни та розведення тварин Вінницького національного аграрного університету (вул. Сонячна, 3, м. Вінниця, 21008, Україна, e-mail: julia.p08@ukr.net, http://orcid.org/0000-0002-1727-6105 ).

Кравець Руслан Андрійович - доктор педагогічних наук, доцент, завідувач кафедри української та іноземних мов Вінницького національного аграрного університету (вул. Сонячна, 3, м. Вінниця, 21008, Україна, e-mail: krawezj@ukr.net, https://orcid.org/0000-0002-7459-8645 ).

Купчук Игорь Николаевич - кандидат технических наук, доцент кафедры общетехнических дисциплин и охраны труда Винницкого национального аграрного университета (ул. Солнечная, 3, г. Винница, 21008, Украина, e-mail: kupchuk.igor@i.ua, http://orcid.org/0000-0002-2973-6914 ).

Побережец Юлия Николаевна - кандидат сельскохозяйственных наук, доцент кафедры (ул. Солнечная, 3, г. Винница, 21008, Украина, +380982248856, e-mail: julia.p08@ukr.net , http://orcid.org/0000-0002-1727-6105 ).

Кравец Руслан Андреевич - доктор педагогических наук, доцент, заведующий кафедрой украинского и иностранных языков Винницкого национального аграрного университета (ул. Солнечная, 3, г. Винница, 21008, Украина, e-mail: krawezj@ukr.net, https://orcid.org/0000-0002-7459-8645 ). 